\title{
RUSKÉ DENNÍKY AKO INTERSEMIOTICKÝ PREKLAD
}

\author{
DAGMAR INŠTITORISOVÁ \\ Filozofická fakulta Univerzity Konštantína Filozofa v Nitre
}

\begin{abstract}
Abstrakt: Príspevok sa zaoberá problematikou využitia prekladových stratégií pri vytváraní typov recipientských interpretácií. Autorka sa v úvodných častiach venuje všeobecnej charakterizácii chápania problematiky prekladu v divadelnom umení, rámcovo sa zaoberá aj problémom polytextovosti divadelného diela a permanentnej performatívnej významovej či výrazovej otvorenosti dramatického/inscenačného textu vo vztahu $k$ danej téme. V exkurze do histórie a súčasnosti prekladu, a to najmä vo vzt̉ahu k divadelnému/dramatickému umeniu, poskytuje väčší priestor Aristotelovi, ruskému lingvistovi Romanovi Osipovičovi Jakobsonovi, slovenskému teatrológovi Petrovi Karvašovi a literárnemu vedcovi Antonovi Popovičovi. Dôvodom je často zásadný podiel uvedených osobností pri chápaní problematiky intersemiotického prekladu a možnosti aplikácie výsledkov ich výskumov pre divadelné/dramatické umenie. Záver príspevku patrí analýze sémantických posunov inscenácie Ruské denníky (Slovenské národné divadlo, 2019) podla semiotickej klasifikácie prekladov Romana Jakobsona.
\end{abstract}

Kl'účové slová: recipientská interpretácia, divadelné dielo, polytextovost', intersemiotický preklad, Roman Osipovič Jakobson, aplikácia, limity, Ruské denníky

Zámerom a ambíciou recipientskej interpretácie umeleckého diela - aj vzhl'adom na jej holistický a hermeneutický základ - je snaha vypovedat’ o skúmanom fakte čo najúplnejšie, najcelistvejšie a najdôslednejšie. Celostné uchopenie je v prípade divadelného umenia vel’mi komplikovaným a náročným činom. Vyplýva to z členitej, rozmanitej a zložitej štruktúry divadelnej inscenácie, a tiež z toho, že divadelný znakový systém využíva či rozvíja aj iné znakové systémy (výtvarné, literárne, hudobné, tanečné umenie atd'.). Na úrovni textu - tak dramatického, aj ako inscenačného - je možné divadelný tvar zo štrukturalistického hl'adiska i z hl'adiska teórie textu označit’ za polytextový systém. Pre každý prvok v jeho okolí je príznačná i kontextovost', ktorá v rozhodujúcej miere ovplyvňuje konotačnú čitatelnost' jednotlivostí tvaru aj jeho celku. Zároveň sa celý znakový systém vyznačuje nestabilnostou, ktorá vyplýva z nemožnosti jeho výrazovej a významovej fixácie vcelku, čo je jednou z d’alších príčin vel'kej rozmanitosti prístupov k uchopeniu jeho koncepčného jadra. ${ }^{1}$ Jednou z odpovedí na otázku, ako vytvorit také vyjadrenie o recipovanom umeleckom diele, ktoré nebude neprimerane obsiahle, je možnost’ pozriet’ sa na problematiku prostredníctvom teórie prekladu, semiotiky a vzt’ahov medzi nimi.

\footnotetext{
${ }^{1}$ Podl'a INŠTITORISOVÁ, D. Divadelná interpretácia ako tvorivé imaginatívne bytie v procese. In INŠTITORISOVÁ, D. Interpretácia divadelného diela. Nitra : Univerzita Konštantína Filozofa, 2010, s. 91 - 92.
} 


\section{Teória prekladu a dramatické umenia}

Problematika teórie prekladu je v rámci divadelnej vedy najčastejšie spätá s otázkami prekladu dramatických textov do cudzích, t. j. iných jazykov. Na Slovensku sa jej venovali či venujú napr. (v abecednom poradí) Martina Borodovčáková, Jana Bžochová-Wild, Jana Cviková, L’ubomír Feldek, Antónia Filipková, Edita Gromová, Soňa Hodáková, Juraj Hubinák, Emília Janecová (vyd. Perez), Daniela Müglová, Ol'ga Ruppeldtová, Dušan Slobodník, Zuzana Starovecká, Juraj Šebesta, Ján Vilikovský a d’alší. K nim môžeme priradit’ aj jazykovedca Jozefa Mistríka, najmä vd’aka jeho monografii Dramatický text (1979), či pol'skú teatrologičku Lucynu Spyrka, ktorá napísala o. i. štúdiu venovanú prekladatel'ským stratégiám L'ubomíra Feldeka (2006) ${ }^{2}$. Ako ale konštatuje slovenská translatologička Edita Gromová, napr. v štúdii Preklad dramatických textov v reflexii translatologického výskumu (2013), súčasná problematika prekladu je zložitá a široká. Dôvodom je skutočnost', že tradičné výskumné translatologické, lingvistické, literárnovedné, sociokultúrne a estetické témy nepostačujú, pretože preklad „(...) dramatických textov modifikuje aj šírka definície dramatického textu. V minulosti sa výskum sústred’oval bud' na dramatické texty určené na javiskové stvárnenie, na inscenovanie, alebo na dramatické texty určené na knižné vydanie, teda na čítanie. Dnes sa aj vd’aka elektronickým médiám (televízia, rozhlas, video, DVD) definícia dramatického textu rozširuje o audiovizuálnu dimenziu. “3 Gromová tiež konštatuje, že preklad „(...) týchto nových typov textov si totiž vyžaduje aj zvláštne prekladatel’ské postupy, ktoré sú ovplyvnené práve multimediálnym charakterom diskurzu (napr. preklad pre audiovizuálne médiá - titulkovanie a dabing)“. ${ }^{4}$

Nielen k multimediálnemu, ale aj intermediálnemu, polymediálnemu, polyformnému, multimodálnemu, polygenetickému, polykódovému, polysémantickému, polytextovému, transformačnému, komunikačnému, reinterpretačnému, simultánnemu, intersemiotickému (a i.) charakteru dramatického textu sa už vyjadrilo vel’a domácich i zahraničných divadelných vedcov, translatológov, lingvistov, estetikov, teoretikov performatívnych štúdií atd'. Aj ked’ je často základom ich uvažovania dramatický text, vzhl’adom na jeho určenie pre kolektívnu, nie individuálnu vizuálnu a akustickú komunikáciu v inom, t. j. divadelnom, filmovom, televíznom, rozhlasovom atd'. jazyku sa tieto pojmy používajú nielen v súvislosti s ním. Označujú aj d’alšie typy prekladových situácií, ktorých je dramatický text súčastou, vd’aka čomu sa vztahujú nielen na divadelné, ale prípadne i na všetky ostatné druhy dramatických diel. Vzhl'adom na spôsob existencie divadelného diela - ako interpretačného bytia ${ }^{5}$ tak v autorskej ako aj recepčnej polohe, je preklad tým teoretickým švom, ktorý spája akékol’vek jeho prvky do zmysluplného celku.

\footnotetext{
${ }^{2}$ Pozri SPYRKA, L. Koncepcja przekładu L’ubomíra Feldka w kontekście słowackiej myśli przekładoznawczej In Przekłady Literatur Słowiańskich, 2016, roč. 7, č. 1, s. $64-77$.

${ }^{3}$ GROMOVÁ, E. Preklad dramatických textov v reflexii translatologického výskumu. In JANECOVÁ, E. - KRÁL'OV Á, B. Preklad a divadlo. Tvorivé prekladatel'ské reflexie 2. Nitra : Univerzita Konštantína Filozofa, 2013, s. 15.

${ }^{4}$ Tamže, s. 16.

${ }^{5}$ Viac pozri INŠTITORISOVÁ, D. Divadelné dielo ako interpretačné bytie. In KUNDEROVÁ, R. Tendence v současném myšlení o divadle. Ad honorem prof. PhDr. Ivo Osolsobě. Sborník z konference Divadelní fakulty Janáčkovy akademie múzických umění v Brně konané 5. a 6. prosince 2008. Brno : Janáčkova akademie múzických umění, 2010, s. 207 - 248.
} 
Pod divadelným dielom chápeme inscenačný text, ktorý je recipovaný nielen autormi, ale už aj divákmi, pričom jeho súčastou môže byṫ tak písaný, ako aj iba hovorený (orálny) dramatický text. Preklad - či už ho chápeme ako proces, text ${ }^{6}$, alebo iba ako akt „okamihu“ recipovania - je tým, ktorý vypĺn̆a „medzeru“ (medzitextový entropický priestor) v akomkol'vek type spojív divadelného textu. Otvorenost' prekladového textu, prekladatel'ského procesu i prekladového aktu úzko súvisí s interpretačnou podstatou divadelného diela, ktorá je spätá so širokou škálou základných a synonymických významov, ako napr. vykladat', vysvetl'ovat', prekladat', tlmočit, vyložit, preložit', rozumiet', porozumiet', chápat', vediet' atd'., ${ }^{7}$ ktoré svedčia nielen o jeho nevyhnutnom subjektívnom výraze, ale aj o kreativite ukotvenej v samotnej konštrukcii textu.

Na problematiku rôznych typov divadelných (či v širšom zmysle slova esteticko-dramatických) prekladatel'ských situácií, ktoré sa vztahujú na divadelné dielo, sa dá pozriet nielen z hl'adiska kategorizácie prekladových spojov. Ďalšou možnostou, ktorá napomôže osvetlit' problematiku, je otázka permanentnej performatívnej významovej, resp. výrazovej otvorenosti dramatického/inscenačného textu. Či už ide o čítanie alebo inscenovanie (vrátane recepcie), v mnohých konceptoch z oblasti teórie drámy, teórie divadelnej inscenácie alebo teórie textu ako takého nájdeme vel’a príkladov. A to počnúc Aristotelom a jeho mimetickým rozmerom tragických dramatických textov, pokračujúc napr. ruským lingvistom Romanom Osipovičom Jakobsonom i slovenským teatrológom Petrom Karvašom a končiac napr. literárnym vedcom Antonom Popovičom. ${ }^{8}$

Aristotelova koncepcia dramatického/inscenačného textu (t. j. aj divadelného diela) prezentuje chápaním pojmu mimézis ${ }^{9}$ ako tvorivého zobrazenia skutočnosti $\mathrm{v}$ jednotlivých zložkách nielen performatívny koncept prístupu k dramatického textu (dielu), ale zároveň určuje základný limit prekladu - nevyhnutnost’ ikonickosti ${ }^{10}$ vo vzt’ahu ku skutočnosti. Nájdeme ju prítomnú na mnohých miestach Aristotelovej definície tragédie, napr. v požiadavkách na skrášlenie textu tragédie rytmom, melódiou či spevom, na napodobnenie, ktoré majú sprostredkovat’ herci, či na všeobecnú určenost' na scénické predvedenie atd..11

\footnotetext{
${ }^{6}$ Oba významy sú v súlade s výkladom pojmu preklad, ako ho uvádza Krátky slovník slovenského jazyka: 1. (pre)tlmočenie textu do iného jazyka: volný, doslovný p., simultánny p.; 2. text preložený do iného jazyka. In KOLEKTÍV. Krátky slovník slovenského jazyka. [online]. [cit. 31. 03. 2020]. Dostupné na internete: https://

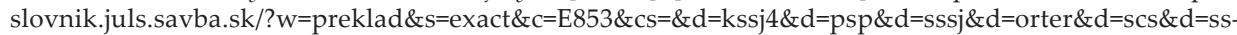
$\mathrm{s} \& \mathrm{~d}=$ peciar $\& \mathrm{~d}=\mathrm{hssj} V \& \mathrm{~d}=$ bernolak $\& \mathrm{~d}=$ noundb\&d=orient $\& \mathrm{~d}=$ locutio\& $\mathrm{d}=$ obce \&d=priezviska\&d=un\&d=pskcs\&d=psken\#.

${ }^{7}$ Napríklad ŠPAŇÁR, J. - HRABOVSKÝ, J. Latinsko-slovenský - slovensko-latinský slovník. Bratislava : Slovenské pedagogické nakladatel'stvo, 1987, s. 320; TVRDÝ, P. Slovník slovensko-latinský. Ružomberok : „Lev“" a Kníhtlačiarsky a nakladatel'ský spolok účastinná spoločnost', 1923, s. 320; PRAŽÁK, J. M. - NOVOTNÝ, F. - SEDLÁČEK, J. Latinsko-český slovník. A - K. Praha : Státní pedagogické nakladatelství, 1955, s. 720 a i.

${ }^{8}$ Vzhl'adom na priestorové a tematické možnosti formy štúdie považujeme zvolené koncepcie za dostatočne preukazné, t. j. nepovažujeme za dôležité rozširovat’ pohl'ady do histórie alebo súčasnosti danej problematiky.

${ }^{9}$ Pôv. mímésis - pojem sa používal najprv v pythagorejskej hudobnej teórii v 5. st. p. Kr. vo význame tanečné zobrazenie. Podla MEISTER, M. Predobraz a nápodoba I. K dejinám divadelnej mimézis. In KOLEKTÍV. Mimézis \& reprezentácia. Bratislava : Sorosovo centrum súčasného umenia, 2000, s. 13.

${ }^{10} \mathrm{~V}$ zmysle chápania ikonu americkým logikom a pragmatikom Ch. S. Peirceom ide o znak vztahujúci sa k objektu, ktorý denotuje na základe podobnosti.

${ }^{11}$ Podla ARISTOTELES. Poetika. Rétorika. Politika. Bratislava : Tatran, 1980, s. 20.
} 
Uvedená predurčenost’ oboch typov textov (divadelného diela) sa vyskytuje v prácach Petra Karvaša na mnohých miestach. Ide o analýzy komunikačnej a interpretačnej podstavy divadelného umenia/diela, pomocou ktorých poukazuje na rôzne typy koexistencie základných divadelných zložiek. Napríklad prítomnost’ výtvarných prvkov zistuje u rozličných autorov tak divadelného, ako aj iného umeleckého zamerania, pretože - ako píše - gestikulácia, mimika a vel'ká čast' pohybu herca patria do výtvarnej tvorby herca, pôdorysné rozvrhnutie scény je zase výsledkom práce režiséra, autorom návrhu scény je divadelný výtvarník (scénograf). ${ }^{12}$ Vzhl'adom na skutočnost', že scénický priestor je fyzicky trojrozmerný, Karvaš považuje divadelnú výtvarnú tvorbu predovšetkým za tvorbu architektonickú, pričom „v jednotlivých štádiách vývinu divadelného výtvarníctva konštatujeme väčšiu alebo menšiu účast' umenia maliarskeho alebo sochárskeho (....). ${ }^{13}$ Analogicky postupuje pri ostatných zložkách - aj pre neustále poukazovanie či už na syntetickost’ alebo synkretickost’ spätosti zložiek a funkcie divadelného umenia má jeho prístup najmä performatívny rozmer.

Anton Popovič ${ }^{14}$ je známy v slovenskom a českom, ale aj v širšom medzinárodnom kontexte - v Pol'sku, Rusku, krajinách bývalej Juhoslávie, Nemecku, Mad’arsku, Vel'kej Británii, Spojených štátoch amerických, Kanade a i. V rámci svojej koncepcie semiotického modelovania sveta $\mathrm{v}$ texte vypracoval vel'mi jasný model prekladu literárneho (umeleckého) textu, ktorý síce vychádza z teórie informácie, obsahuje však v sebe otvorenost' voči významovej i výrazovej zmene. A to tým, že pri preklade podla neho ide hlavne o „prekódovanie jazykového textu, pri ktorom dochádza k vytváraniu jeho novej jazykovej podoby a štylistického tvaru. Preklad je prechod textového invariantu z jedného textu do druhého, a to pri maximálnom rešpektovaní výrazových a významových informácií (informácií) originálu. (...) Vzhl’adom na rozdiely, ktoré existujú medzi jazykmi, štýlmi a kultúrami sa originál nemôže realizovat’ v preklade priamočiaro, ale na princípe ekvivalencie (modelovania)." ${ }^{15}$ Prekladatel'ská tvorba i tým, že vytvára štylistický model, je podla neho „e experimentálnou (je metatvorbou)“. ${ }^{16}$

Popovič sa zaoberal aj typológiou umeleckého prekladu. Model, ktorý vypracoval, obsahuje nasledovné komunikačno-prekladatel'ské vektory: autor, text, príjemca, realita, tradícia, prekladatel'ova cenzúra, preklad básne prózou, preklad prózy básňou, redukovaný preklad, rozšírený preklad, autorský preklad (autopreklad), anotovaný preklad, adaptácia, aktualizácia, lokalizácia, tradícia prekladu, príjemca prekladu, realita prekladu, tradícia prekladu, pseudopreklad, sprostredkovaný preklad, kompilatívny preklad, preklad-plagiát. ${ }^{17}$ Definoval tiež vel'ký rad základných typov prekladu, napr. priamy, autorský, slovný, doslovný, vnútroliterárny, vnútrojazyko$\mathrm{vý}^{18}$, utajený polemický, hudobný, preklad textu filmových dialógov, drámy atd'. Vymedzil aj intersemiotický preklad ako preklad „,medzi dvomi znakovými systémami.

\footnotetext{
${ }^{12}$ Vol’ne podl’a podkapitoly KARVAŠ, P. Složka výtvarná. In KARVAŠ P. Úvod do základných problémov divadla. Martin : Ústredie slovenských ochotníckych divadiel, 1948, s. 84 - 97.

${ }^{13}$ Vol'ne podl'a tamže, s. 84 .

${ }^{14}$ Vel’mi podrobne sa o význame A. Popoviča vyjadruje napríklad E. Gromová v štúdii Translation Studies in Nitra. In World Literature Studies, 2009, roč. 4, č. 1, s. 22 - 44. Viac tiež POPOVIČ, A. Teória umeleckého prekladu. Bratislava : Tatran, 1979.

${ }^{15}$ POPOVIČ, A. a kol. Originál-preklad. Interpretačná terminológia. Bratislava : Tatran, 1983, s. 171.

${ }^{16}$ MIKO, F. - POPOVIČ, A. Tvorba a recepcia. Estetická komunikácia a metakomunikácia. Bratislava : Tatran, 1978 , s. 362.

${ }^{17}$ POPOVIČ, A. a kol. Originál-preklad. Interpretačná terminológia, s. 226.

${ }^{18}$ Ide o Jakobsonov intralingválny preklad. Tieto znaky má však u neho viacero typov prekladu.
} 
(...) Ide tu o druh medzisémantickej tranformácie, napr. z jazyka literatúry do jazyka filmu, z jazyka výtvarného umenia do jazyka hudby a pod. ${ }^{\text {} 19} \mathrm{~V}$ definícii prekladu drámy považuje za špecifikum napr. potrebu zameranosti na repliky, ich modálne zafarbenie z hl'adiska spôsobu rozprávania, vzt’ahov medzi postavami, charakterizácie postáv, hereckej akcie, situácie, scény atd’. Hlavným znakom dramatického dialógu je podl'a neho výrečnost', t. j. dobrá vyslovitel'nost' a zrozumitel'nost', a to aj napriek štylizovanosti jazyka. ${ }^{20}$ Dôvodom je skutočnost', že jeho primárnou určenostou „nie je byt čítaný (...), jeho hlavnou funkciou je byt’ podkladom pre inscenáciu“. ${ }^{21}$

Na Popovičov model prekladovej komunikácie nadväzuje Edita Gromová, ktorá rozvíja postavenie prekladatel’a ako sprostredkovatel’a bilingválnej komunikácie. ${ }^{22}$ V monografii s názvom Translácia v divadelnej komunikácii (2013), v spolupráci s autorkami Soňou Horňákovou, Emíliou Janecovou, Danielou Müglovou a Antóniou Filipkovou, rozpracovala tento model v súvislosti s hl'adaním paralel medzi teóriou divadelnej komunikácie a teóriou translácie. Autorky predstavili v publikácii nielen základné teoretické východiská, ale jednotlivé aspekty demonštrovali aj na konkrétnych príkladoch. Literárny vedec František Miko, dlhoročný kolega Antona Popoviča, použil na „(...) označenie rozdielu medzi výrazovou hodnotou originálu a výrazovou hodnotou (...) pojem výrazový posun“. ${ }^{23}$ Spolu s Popovičom tak vyriešil aj otázku prirodzenej entropickosti prekladových textov. Pri aplikácii uvedených tvrdení na divadelné dielo/umenie oba pojmy - prekladový výrazový posun a štylistický model - v sebe obsahujú performatívnost' a potvrdzujú taktiež nevyhnutnost' istej miery ikonickosti ako základného limitu prekladu.

Zásadný podiel na riešení problematiky permanentnej otvorenosti ${ }^{24}$ prekladového textu v teoretickej aj aplikačnej rovine - teda i v súvislosti s dramatickými textami/dielami vo všetkých druhoch - má Roman Osipovič Jakobson. Vo svojej štúdii On Linguistic Aspects of Translation (O jazykových aspektoch prekladu, 1959) rozlišuje tri spôsoby interpretácie slovného znaku, ktorý sa môže prekladat’ do iných znakov toho istého jazyka, do iného jazyka, alebo do iného neverbálneho znakového systému. Interpretačný prístup označuje ako:

„1) Intralinguálny preklad alebo preformulovanie slov, ked’ ide o interpretáciu slovných znakov pomocou iných znakov toho istého jazyka.

2) Interlinguálny preklad alebo vlastný preklad, ktorý je výkladom slovných znakov pomocou iného jazyka.

3) Intersemiotický preklad alebo transmutácia, ktorý je interpretáciou slovných znakov pomocou znakov neverbálnych signálnych systémov. “25

\footnotetext{
${ }^{19}$ POPOVIČ, A. a kol. Originál - preklad. Interpretačná terminológia, s. 220.

${ }^{20}$ Podla (eh) [HOROVÁ, E.]. Preklad drámy. [Heslo]. In tamže, s. 239.

${ }^{21}$ Tamže.

${ }^{22}$ Podl’a GROMOVÁ, E. Interpretácia v procese umeleckého prekladu. In ŽILKA, T. Textové podoby postmoderny. Vizuálna poézia, próza, dráma. Nitra : Univerzita Konštantína Filozofa, 1996, s. 218 - 219.

${ }^{23}$ VALENTOVÁ, M. - REŽNÁ, M. Aspekty prekladového textu. Antológia prác o preklade. Nitra : Univerzita Konštantína Filozofa, 2011, s. 11.

${ }^{24}$ I ked' v súvislosti s týmto pojmom je viac známa a populárnejšia monografická prvotina Umberta Eca Opera aperta (1962).

${ }^{25}$ JAKOBSON, R. On Linguistic Aspects of Translation. In BROWER, R. A. On Translation. Cambridge, Massachusetts : Harvard University Press, 1959, s. 233. Citáty z textov publikovaných v cudzích jazykoch prel. D. P.
} 
Svoje zistenie zároveň aplikoval na oblast’ poetiky, pri ktorej konštatuje, že je „možná iba kreatívna transpozícia: bud’ intralingválna transpozícia - z jedného poetického tvaru do druhého, alebo interlinguálna transpozícia - z jedného jazyka do druhého, alebo nakoniec intersemiotická transpozícia - z jedného systému znakov do druhého, napr. od verbálneho umenia po hudbu, tanec, kino alebo mal'ovanie. " ${ }^{26}$

Platnost' tejto charakterizácie prekladových špecifík differentia specifica možno bez problémov aplikovat' i na osobitosti jazyka divadelného umenia vo vztahu ku každému jeho druhu, forme či typu, aj vo vztłahu k ostatným umeniam. Relevantné je tiež Jakobsonovo chápanie intersemiotického prekladu ako medzidruhového posunu. V rámci estetiky dramatických umení sa viac pracuje s jeho poetickou, referenčnou, emotívnou, konatívnou, fatickou a metajazykovou funkciou, ${ }^{27}$ prostredníctvom ktorých sa poukazuje na základné vlastnosti divadla ako umenia, než s uvedenými tromi základnými typmi prekladu, ktoré pristupujú k artefaktom v omnoho širšom kontexte.

\section{Intersemiotický preklad a dramatické umenia}

V tejto časti textu priblížime prostredníctvom niekol'kých ukážok najmenej častý, intersemiotický typ prekladu. Napriek tomu, že poskytuje najväčšie možnosti využitia pre oblast’ dramatických umení, divadelní (dramatickí) umelci sa zaoberajú predovšetkým intralingvistickým prekladom, ktorý je aj teoreticky najviac rozpracovaný.

$S$ intersemiotickým typom pracoval napríklad Ivo Osolsobě ${ }^{28} \mathrm{v}$ monografii Mnoho povyku pro semiotiku (1992), ktorý pri sériovom poňatí komunikačnej situácie charakterizuje spôsob pretvárania Správy ${ }^{1}$ na Správu² ako intersemiotický preklad. ${ }^{29}$ Slovenská teoretička a historička médií Lenka Regrutová s ním pracuje napríklad v štúdii Transformácia slovenskej l’udovej rozprávky do prostredia akusticko-auditívnej komunikácie (2012) pri analýze vztahu Dobšinského rozprávok a ich rozhlasových adaptácií. Konštatuje, že v procese intersemiotického posunu okrem „konštantnej štruktúrnej premeny (zmena dvoch znakových systémov) sú potrebné aj viac premenlivé zmeny v ideovo-tematickej rovine diela, kedy dochádza k aktualizácii a individuálnej konkretizácii (zo strany autora aj príjemcu, vplyvom meniaceho sa historického a spoločenského kontextu), ale aj ku skracovaniu, eliminovaniu, selekcii a d’alším zmenám prototextu. Charakter a rozsah transformačných zásahov vplýva na rozlíšenie dramatizačných prístupov. Zjednodušene povedané, ide o tesnejší alebo volnejší vzt̉ah k predlohe, ktorý predstavuje snahu o doslovný prepis pôvodného diela (,reprodukcia literárnej predlohy') alebo vol’nú inšpiráciu motívom, myšlienkou, postavou (adaptácia na motívy, vol'ná adaptácia, parafráza, variácia na predlohu) s rôznymi prechodovými pásmami. “30

\footnotetext{
${ }^{26}$ Tamže, s. 238.

${ }^{27}$ JAKOBSON, R. Lingvistika a poetika. [online]. [cit. 28. 3. 2020]. Dostupné na internete: https://www.ucl. cas.cz/edicee/images/data/prirucky/obsah/pruvodce/Lingvistika\%20a\%20poetika.pdf

${ }^{28} \mathrm{Nie}$ každý autor/každá autorka uvedený/á v tejto štúdii nadväzoval na R. Jakobsona. Medzi autorov, ktorí pri intersemiotickom preklade nevychádzali z R. Jakobsona, patria napr. Eva Zienkiewicz-Franczak, Marek Hendrykowski, Lenka Regrutová a i.

${ }^{29}$ Podl’a OSOLSOBĚ, I. Mnoho povyku pro semiotiku. Brno : Agentura G, 1992, s. 27.

${ }^{30}$ REGRUTOVÁ, L. Transformácia slovenskej ludovej rozprávky do prostredia akusticko-auditívnej komunikácie. [online]. [cit. 28. 3. 2020]. In Jazyk a reč, 2012, roč. 3, č. 9, s. 1. Dostupné na internete: http://www. ff.unipo.sk/jak/rus/9_2012/regrutova.pdf.
} 
Pol’ský filmológ Marek Hendrykowski v štúdii s názvom Adaptacja jako przekład intersemiotyczny (Adaptácia ako intersemiotický preklad, 2013) pri filmovom umení v súvislosti s intersemiotickým prekladom vysoko oceňuje skutočnost', že sa „dávno naučilo prispôsobit’ si vlastným potrebám všetko (obrazový príbeh, divadelné predstavenie, operu, román, komiks, tlačovú správu, súdne správy, intímny denník, starodávnu drámu, mýtus, legendu, reportáž, fotografiu, pieseň, kresbu, mallbu, kuchynské čalúnenie, tetovanie atd’) (...),"31 pretože si tak od svojho počiatku odskúšalo rôzne jeho formy, často vel'mi odvážne a s prekvapivými výsledkami. ${ }^{32}$ Aj ked' konštatuje, že doteraz nie sú špecifikované základné formy filmovej adaptácie ako intersemiotického prekladu, filmovú adaptáciu za takýto typ prekladu považuje. ${ }^{33}$ Pol'ská lingvistka Seweryna Wysłouch zase v štúdii Adaptacja filmowa - przekładem czy montażem? (Filmová adaptácia - preklad alebo montáž?, 2014) v súvislosti s charakterizáciou filmovej adaptácie ako intersemiotického prekladu píše, že adaptáciu nemožno chápat iba ako jednoduchú montáž hotových prvkov, pretože nemá iba technický charakter, ale ide o operácie, ktoré sa hlboko dotýkajú štruktúry predlohy tým, že ide o "preklad“ verbálneho jazyka do „pohyblivých“ obrazov. Pre tento proces sú príznačné rôzne sémantické tranformácie ako adícia, inverzia, kompresia, amplifikácia atd'. ${ }^{34}$

Česká translatologička Zuzana Korábová v diplomovej práci s názvom Komparace posunư v intersémiotickém a mezijazykovém překladu divadelní hry Václava Havla Odcházení (2015) považuje intersemiotický predklad za vhodnú metódu pri zistovaní metajazykových posunov, pričom v súvislosti s problematikou filmovej adaptácie používa termín intersemiotická situácia. Uvádza tiež viacero príkladov z oblasti dramatických umení, napr. „simultánne tlmočenie do znakového jazyka, komiks vychádzajúci z oblúbeného seriálu alebo baletné predstavenie na motívy známej rozprávky“35. Edita Gromová, Soňa Hodáková, Emília Perez a Andrej Záhorák, autori kolektívnej monografie s názvom Audiovizuálny preklad a nepočujúci divák. Problematika titulkovania pre nepočujúcich (2016), konštatujú, že „v prípade výroby audiokomentára pre nevidiacich divákov sa uplatňuje pri verbálnom prenose informácií z vizuálnej roviny na rovinu zvukovú, naopak, pri titulkovaní pre nepočujúcich ide o verbálny prenos informácií z roviny zvuku na vizuálnu rovinu“ ${ }^{\prime 36}$. Autori d’alej píšu: „Osobitnú kategóriu predstavuje tlmočenie audiovizuálnych diel do posunkového jazyka nepočujúcich, ktoré možno uchopit’ optikou intersemiotického prenosu, ale i z hladiska prekladu interlingválnej translácie. Rozhodujúcim faktorom je pritom postoj $\mathrm{k}$ chápaniu jazyka nepočujúcich či vymedzeniu komunity nepočujúcich ako jazykovej a kultúrnej menšiny. ${ }^{\text {37 }}$ Proces titulkovania pre nepočujúcich d’alej charakterizovali ako ten, ktorý „,analogicky s interlingválnym titulkovaním pre po-

${ }^{31}$ HENDRYKOWSKI, M. Adaptacja jako przekład intersemiotyczny. In Przestrzenie Teorii, 2013, roč. 22, č. 20, s. 177 .

${ }^{32}$ Tamže.

${ }^{33}$ Tamže, s. 183 - 184.

${ }^{34}$ WYSŁOUCH, S. Adaptacja filmowa - przekłademczy montażem? In Przestrzenie Teorii, 2014, roč. 23, č. 22 , s. $223-227$.

${ }^{35}$ KORÁBOVÁ, Z. Komparace posunů v intersémiotickém a mezijazykovém překladu divadelní hry Václava Havla Odcházení. [Diplomová práca]. Praha : Univerzita Karlova, 2015, s. 7.

${ }^{36}$ GROMOVÁ, E. - HODÁKOVÁ, S. - PEREZ, E. - ZÁHORÁK, A. Audiovizuálny preklad a nepočujúci divák. Problematika titulkovania pre nepočujúcich. Nitra : Univerzita Konštantína Filozofa, 2016, s. 10.

${ }^{37}$ Tamže. 
čujúcich recipientov podlieha z formálneho hl'adiska nielen časovým, ale i priestorovým obmedzeniam“"38.

Holandská semiotička a lingvistka Dinda L. Gorlée sa v štúdii s názvom Intersemioticity and intertextuality: Picaresque and romance in opera (Intersemiotika a intertextualita: pikaresknost’ a romanca v opere, 2016) zaoberá vzt'ahom jazyka libreta, hudby a následne vzt̉ahom opery ako dramatického umenia $\mathrm{k}$ nim. Upozorňuje tiež na skutočnost', že libreto prechádza pri uvádzaní na javisko rôznymi intersemiotickými operáciami. Za najčastejšie operácie považuje javiskovú interpretáciu libreta, ktoré sa inscenuje ako výsledok muzikologického výskumu hudobnej partitúry, rukopisu autora hudby či dobovej hudby, a výskumu literárneho príbehu, avšak obe sú iba povrchom libreta, pretože jeho „javiskový dramatický obsah nie je čistou fantáziou, ale výsledkom jeho intersemiotického charakteru. Intersemiosis súvisí s dejinami kultúry, ktorá tvorí podstatu dramatickosti opery. Libreto pretvára operná rétorika, ktorá prevzala ,vonkajší' symbolizmus kolektívneho folklóru a archetypu mytológie. “39

Lingvistka a pedagogička pol'ského jazyka Eva Zienkiewicz-Franczak sa vo svojej dizertačnej práci s názvom Przekład intersemiotyczny w edukacji polonistycznejs (Intersemiotický preklad vo výučbe pol'ského jazyka, 2018) venuje vztahom rôznych typov umeleckých textov a možnosti vysvetlenia ich podstavy vo vzdelávacom procese aj prostredníctvom vel'kého množstva konkrétnych ukážok práce s umeleckými dielami. Za základ prístupu považuje intersemiotickú interpretáciu, ktorá je pre ňu dialogickým spôsobom organizácie textov. ${ }^{40}$ Rumunská translatologička Aba-Carina Parlog v monografii Intersemiotic Translation. Literary and Linguistic Multimodality (Intersemiotický preklad. Literárna a lingvistická multimodalita, 2019) pri intersemiotickom preklade považuje za dôležité „vytvorenie paralelných skupín znakov, medzi ktorými je možné dosiahnut' prenos. Tieto môžu odkazovat' bud' na umenie alebo literatúru, ak má človek záujem zaoberat’ sa ekfrázou, alebo môžu patrit’ k iným typom symbolického znázornenia, ktoré môže mat’ rôzne podoby. ${ }^{\text {11 }}$

\section{Ruské denníky a intersemiotický preklad}

V nasledujúcej časti štúdie demonštrujeme uplatnenie Jakobsonovej semiotickej klasifikácie typov prekladov na príklade inscenácie Ruské denníky (Slovenské národné divadlo, 2019, réžia Roman Polák ${ }^{42}$, a to v celej komunikačnej situácii:

Intralingálny preklad

Autobiografia:

- úpravy rukopisu súvisiace s finálnymi úpravami autorky autobiografie pred odovzdaním na spracovanie rukopisu vydavatelom;

\footnotetext{
${ }^{38}$ Tamže, s. 21.

${ }^{39}$ GORLÉE, L. D. Intersemioticity and intertextuality: Picaresque and romance in opera. In $\Sigma \eta \mu \varepsilon \iota \omega \tau \kappa \eta$ - Sign Systems Studies, 2016, roč. 44, č. 4, s. 590.

${ }^{40}$ Podla ZIENKIEWICZ-FRANCZAK, E. Przekład intersemiotyczny w edukacji polonistycznejs. [Dizertačná práca]. Poznań : Uniwersytet im. Adam Mickiewicz, 2018, s. 130. [online]. [cit. 22. 3. 2020]. Dostupné na internete: https://repozytorium.amu.edu.pl/handle/10593/22924.

${ }^{41}$ PÂRLOG, A-C. Intersemiotic Translation. Literary and Linguistic Multimodality. Cham : Palgrave Pivot, 2019, s. 3.

42 Ala Rachmanovová - Roman Polák: Ruské denníky. Slovenské národné divadlo, Bratislava, premiéra 20. 4. 2019. Preklad Zuzana Demjanová, dramatizácia Roman Polák, dramaturgia Daniel Majling, scéna Pavel Borák, kostýmy Peter Čanecký, hudba Lucia Chutkková, video Lukáš Kodoň, réžia Roman Polák.
} 
- redakčné, jazykové a autorské úpravy rukopisu súvisiace s prvým vydaním autobiografickej pôvodiny;

- rôzne formy prerozprávania obsahu autobiografie autorkou.

Dramatizácia:

- úpravy autora dramatizácie súvisiace s finálnymi úpravami pred odovzdaním dramaturgovi divadla, prípadne inej osobe zodpovednej za prevzatie rukopisu;

- úpravy dramatizácie po pripomienkovaní dramaturgom;

- úpravy dramatizácie na základe pripomienok hercov či d’alších spolutvorcov inscenácie;

- redakčné, jazykové a autorské úpravy dramatizácie súvisiace s jej publikovaním $\mathrm{v}$ bulletine divadla.

Interlinguálny preklad:

Autobiografia:

- preklad originálu do nemeckého jazyka autorkiným manželom ${ }^{43}$;

- preklady literárnej predlohy Ale Rachmanovovej do rôznych jazykov ${ }^{44}$.

Dramatizácia:

- preklad dramatizácie do iných jazykov ${ }^{45}$;

- naštudovanie inscenácie $\mathrm{v}$ inom divadle ${ }^{46}$

Intersemiotický preklad:

Autobiografia:

- literárne spracovanie života autorky predlohy;

- grafický dizajn spracovania literárnej predlohy vo vydaniach;

- informácie o literárnej predlohe v bulletine k inscenácii;

- informácie o literárnej predlohe v online priestore v súvislosti s inscenáciou;

- odcitovanie častí literárnej predlohy počas predstavení;

- filmové, rozhlasové a pod. dielo ${ }^{47}$.

Dramatizácia:

- grafické spracovanie dramatizácie v bulletine k inscenácii;

- inscenácia dramatizácie;

- dramaturgia inscenácie;

- realizácia scénografického návrhu;

- realizácia kostýmového návrhu;

- realizácia scénickej hudby;

- realizácia videonahrávok do inscenácie;

- bulletin k inscenácii (vrátane dizajnu);

\footnotetext{
${ }^{43}$ Ani jeden prekladatel' nemal k dispozícii originál, ktorý dala autorka iba manželovi. Podla DEMJÁNOVÁ, Z. Doslov. In RACHMANONOVÁ, A. Ruské denníky, 1916 - 1927. Bratislava : Premedia, 2017, s. $650-651$.

${ }^{44}$ Vrátane nevydarených prekladov, akým je napr. český preklad z roku 1938 (vydavatel’stvo Vyšehrad), v ktorom vydavatel' svojvolne obmieňal znenie textu, zvýrazňoval iné významy či dokonca vypúštal pasáže, ktoré svedčili o morálnom úpadku a chudobe československých légií na Sibíri. Podl’a DEMJÁNOVÁ, Z Doslov. In RACHMANOVOVÁ, A. Ruské denníky, 1916 - 1927, s. 651.

${ }^{45}$ Pozn. autorky: v súčasnosti ešte neexistuje.

${ }^{46}$ Pozn. autorky: v súčasnosti ešte neexistuje.

${ }^{47}$ Pozn. autorky: v súčasnosti ešte neexistuje.
} 
- videoukážky z prípravy inscenácie, vyjadrenia režiséra, dramaturga, hercov atd’. vo videách o príprave inscenácie, plagáty na webe divadla či na iných webových sídlach atd';

- anotácie o inscenácii, tlačové správy, informácie o inscenácii (dramatizácii, dramaturgii atd'.) na webe divadla či na iných webových sídlach;

- prevzatie predstavenia televíziou;

- televízna relácia o príprave inscenácie;

- ohlasy o inscenácii v printových médiách (správy, recenzie, štúdie, odborné články, analýzy atd’.);

- ohlasy o inscenácii v elektronických médiách, v online denníkoch, časopisoch, televízii, rozhlase a pod. (správy, kritiky, komentáre, rozhovory atd'.);

- diskusie na tému inscenácie mimo štandardného verejného priestoru určeného na reflexiu inscenácie, aj nezaznamenávané.

\section{Záver}

Z uvedených príkladov je zrejmé, že vzhl’adom na povahu divadelného diela i divadelného umenia je najviac zastúpený intersemiotický preklad. Príklady sú však iba enumeráciou foriem intersemiotického prekladu, ktorá vychádza z analýzy základnej situácie. Pri každej z foriem uvedeného sémantického posunu je potrebné ešte sledovat' ich performatívnu a ikonickú rovinu, t. j., je potrebné výrazovo a významovo zachytit', ako sa v texte/diele kreovala téma, námet, koncepcia atd’. Taktiež je dôležité zistit', či sú všetky základné výrazové prostriedky divadelného jazyka formulované tak, aby metavyjadrenie (t. j. novovzniknutá interpretácia) spíňalo základné podmienky recepčnej interpretácie. Vzhl'adom na to, že z textu musí byt̉ jasné, čo ním chce autor vyjadrit', musí byt' zrozumitel’ne vysvetlený nielen jeho zážitok z diela a postoj k nemu. Recipient sa musí zároveň zamerat na hlavné aspekty diela, pričom toto zameranie vytvorí predpoklad vzniku a následného recepčného generovania koncepcie zážitkového imagenu. Teda určí, čo bude zo znakovej štruktúry textu/diela vyzdvihnuté do popredia ako dôležité, a to opät formou znakov, pretože predstavujú najjednoduchší systém na vzájomné porozumenie všetkých účastníkov komunikácie.

\section{RUSKÉ DENNÍKY/RUSSIAN DIARIES AS INTERSEMIOTIC TRANSLATION}

\section{Dagmar INŠTITORISOVÁ}

The paper deals with the issue of using translation strategies in creating types of recipient interpretations. In the introductory parts, the authoress covers the general characterisation of understanding the issue of translation in theatrical art. In general, it also deals with the issue of polytextuality of a theatrical work and a permanent performative semantic or expressive openness of a dramatic/production text vis-à-vis the theme in question. By making an historical digression and via the current status of translation, especially in relation to theatrical/dramatic art, it gives more space to Aristotle, the Russian linguist Roman Osipovich Jakobson, the Slovak theatrologist Peter Karvaš, and to the literary scholar Anton Popovič. The reason is to be sought in the oftentimes fundamental role of these personalities in understanding intersemiotic 
translation and the possibility of applying the outcomes of their research to theatri$\mathrm{cal} /$ dramatic art. The paper concludes with an analysis of the semantic shifts in the production Ruské denníky/Russian Diaries (Slovak National Theatre, 2019, directed by Roman Polák) according to the semiotic classification of the types of translations by Roman Jakobson.

\section{LITERATÚRA}

ARISTOTELES. Poetika. Rétorika. Politika. Bratislava : Tatran, 1980. $279 \mathrm{~s}$.

CÍSǍ̌, Jan. Základy dramaturgie. 1. Situace, 2. Dramatická postava. Praha : Akademie múzických umění, 2009. 139 s. ISBN 978-80-1331-146-9.

DEMJÁNOVÁ, Zuzana. Doslov. In RACHMANONOVÁ, Ala. Ruské denníky, 1916 - 1927. Bratislava : Premedia, 2017, s. 647 - 652. ISBN 978-80-8159-537-0.

ECO, Umberto. Opera aperta. Forma e indeterminazione nelle poetiche contemporanee. Milano : Bompiani Milano, 1962. $370 \mathrm{~s}$.

ECO, Umberto. Semiotics and the Philosophy of Language. Bloomington: Indiana Universiry Press, 1986. 256 s. ISBN 0-153-35168-5.

(eh) (HOROVÁ, Eva). Preklad drámy. [Heslo]. In POPOVIČ, Anton a kol. Originál - preklad. Interpretačná terminológia. Bratislava : Tatran, 1983, s. 238 - 240.

FUJÁK, Július. Tvorivost' v načúvaní hudobného tvaru. Interpretačné sondy do (ne)konvenčnej hudby. Nitra : Univerzita Konštantína Filozofa, 2008. 92 s. ISBN 80-8050-364-8.

GORLÉE, Dinda L. Intersemioticity and intertextuality: Picaresque and romance in opera.

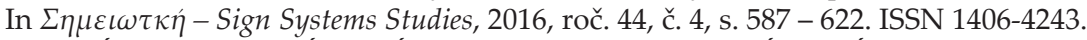

GROMOVÁ, Edita - HODÁKOVÁ, Soňa - PEREZ, Emília - ZÁHORÁK, Andrej. Audiovizuálny preklad a nepočujúci divák. Problematika titulkovania pre nepočujúcich. Nitra : Univerzita Konštantína Filozofa, 2016. 97 s. ISBN 978-80-558-1119-2.

GROMOVÁ, Edita - HODÁKOVÁ, Soňa - JANECOVÁ, Emília - MÜGLOVÁ, Daniela - FILÍPKOVÁ, Antónia. Translácia v divadelnej komunikácii. Nitra : Univerzita Konštantína Filozofa, 2013. 106 s. ISBN 978-80-558-0410-1.

GROMOVÁ, Edita. Interpretácia v procese umeleckého prekladu. In ŽILKA, Tibor. Textové podoby postmoderny. Vizuálna poézia, próza, dráma. Nitra : Univerzita Konštantína Filozofa, 1996, s. 207 - 221. ISBN 80-8050-016-9.

GROMOVÁ, Edita. Preklad dramatických textov v reflexii translatologického výskumu. In JANECOVÁ, Emília - KRÁL’OVÁ, Barbora. Preklad a divadlo. Tvorivé prekladatel'ské reflexie 2. Nitra : Univerzita Konštantína Filozofa, 2013, s. 15 - 30. ISBN 978-80-558-0226-8.

GROMOVÁ, Edita. Translation Studies in Nitra. In World Literature Studies, 2009, roč. 4, č. 1, s. 22 - 44. ISSN 1337-9275.

HENDRYKOWSKI, Marek. Adaptacja jako przekład intersemiotyczny. In Przestrzenie Teorii, 2013, roč. 22, č. 20, s. 175 - 184. ISSN 1644-6763.

HIMIČ, Peter. Dramatický text ako deformácia alebo Môže byt ešte Jung inšpiráciou? In Divadelní revue, 1998, roč. 9, č. 1 , s. $46-49$.

HIMIČ, Peter. Semiotizácia absurdného motívu v Beckettovej tvorbe. In Slovenské divadlo, 1992, roč. 40, č. 1, s. 40 - 43. ISNN 0037-699X.

HLAVENKOVÁ-BAKOŠOVÁ, Zuzana. Intermediálny priestor divadla. In KOLEKTÍV. Divadlo a intermedialita. Divadlo a nové médiá, intermedialita, teatralita, (re)-prezentácia. Bratislava : Vysoká škola múzických umení, 2012, s. 9 - 23. ISBN 978-80-89439-30-0.

INŠTITORISOVÁ, Dagmar. Divadelná interpretácia ako tvorivé imaginatívne bytie v procese. In INŠTITORISOVÁ, Dagmar. Interpretácia divadelného diela. Nitra : Univerzita Konštantína Filozofa, 2010, s. 83 - 97. ISBN 978-80-8094-432-2. 
INŠTITORISOVÁ, Dagmar. Divadelné dielo ako interpretačné bytie. In KUNDEROVÁ, R. Tendence v současném myšlení o divadle. Ad honorem prof. PhDr. Ivo Osolsobě. Sborník z konference Divadelní fakulty Janáčkovy akademie múzických umění v Brně konané 5. a 6. prosince 2008. Brno : Janáčkova akademie múzických umění, 2010, s. 207 - 248. ISBN 978-80-86928-82-1.

INŠTITORISOVÁ, Dagmar. Divadelné dielo z hl'adiska intertextuality. In O výrazovej variabilite divadelného diela. Nitra : Univerzita Konštantína Filozofa, 2001, s. 115 - 134. ISBN 80-8050406-7.

JAKOBSON, Roman. Lingvistika a poetika. [online]. [cit. 28. 3. 2020]. Dostupné na internete: https://www.ucl.cas.cz/edicee/images/data/prirucky/obsah/pruvodce/Lingvistika\%20a $\% 20$ poetika.pdf, s. $370-379$.

JAKOBSON, Roman. On Linguistic Aspects of Translation. In BROWER, Reuben Arthur. On Translation. Cambridge, Massachusetts : Harvard University Press, 1959, s. 232 - 239. ISBN 978-06-7473-161-5.

KARVAŠ, Peter. Priestory v divadle a divadlo v priestore. K problematike svojrázu a špecifickosti divadelného umenia. Bratislava : Tatran, 1984. $581 \mathrm{~s}$.

KARVAŠ, Peter. Reštrukturácia umeleckých potrieb a premeny dramatických umení. Bratislava : Výskumný ústav kultúry, 1982. 177 s.

KARVAŠ, Peter. Složka výtvarná. In KARVAŠ Peter. Úvod do základných problémov divadla. Martin : Ústredie slovenských ochotníckych divadiel, 1948, s. 84 - 97.

KOLEKTÍV. Krátky slovníkslovenskéhojazyka.2003. [online]. [cit.31.03.2020]. Dostupné na internete: https://slovnik.juls.savba.sk/?w=preklad\&s=exact\&c=E853\&cs=\&d=kssj4\&d=psp\&d=ss$\mathrm{sj} \& \mathrm{~d}=$ orter $\& \mathrm{~d}=\mathrm{scs} \& \mathrm{~d}=\mathrm{sss} \& \mathrm{~d}=$ peciar $\& \mathrm{~d}=\mathrm{hssj} V \& \mathrm{~d}=$ bernolak\& $\mathrm{d}=$ noundb\& $\mathrm{d}=$ orient $\& \mathrm{~d}=$ locutio\& $\mathrm{d}=\mathrm{obce} \& \mathrm{~d}=$ priezviska\&d=un\& $\mathrm{d}=$ pskcs\&d=psken\# .

KORÁBOVÁ, Zuzana. Komparace posunư v intersémiotickém a mezijazykovém překladu divadelní hry Václava Havla Odcházení. [Diplomová práca]. Praha : Univezita Karlova, 2015. 83 s.

MEISTER, Monika. Predobraz a nápodoba I. K dejinám divadelnej mimézis. In KOLEKTÍV. Mimézis E reprezentácia. Bratislava : Sorosovo centrum súčasného umenia, 2000, s. 9 - 25. ISBN 80-968089-9-0.

MIKO, František - POPOVIČ, Anton. Tvorba a recepcia. Estetická komunikácia a metakomunikácia. Bratislava : Tatran, 1978. $387 \mathrm{s.}$

MISTRÍK, Jozef. Dramatický text. Bratislava : Tatran, 1979. 224 s.

OSOLSOBĚ, Ivo. Mnoho povyku pro semiotiku. Brno : Nakladatelství „G“ hudba a divadlo, 1992. 223 s. ISBN 80-901112-0-3.

OSTRIHOŇOVÁ, Aňa. Preklad kultúrnych odkazov v audiovizuálnych dielach. In GROMOVÁ, Edita - JANECOVÁ, Emília. Audiovizuálny preklad: výzvy a perspektívy. Nitra : Univerzita Konštantína Filozofa, 2014, s. 90 - 107. ISBN 978-80-558-0572-6.

PÂRLOG, Aba-Carina. Intersemiotic Translation. Literary and Linguistic Multimodality. Cham : Palgrave Pivot, 2019. 80 s. ISBN 978-3-030-16766-0.

PAŠTEKA, Július. Estetické paralely umenia. Štúdie o divadle, dramatike a filme. Bratislava : VEDA, 1976. $425 \mathrm{~s}$.

PAVIS, Patrice. L'analyse Des Spectacles. Théâtre - Mime - Danse - Cinéma. Paris : Nathan Université, 1996. $319 \mathrm{~s}$.

POPOVIČ, Anton a kol. Originál - preklad. Interpretačná terminológia. Bratislava : Tatran, 1983. $367 \mathrm{~s}$.

POPOVIČ, Anton. Teória umeleckého prekladu. Bratislava : Tatran, 1979. 293 s.

PRAŽÁK, Josef Miloslav - NOVOTNÝ, František - SEDLÁČEK, Josef. Latinsko-český slouník. A -K. Praha : Státní pedagogické nakladatelství, 1955. $1348 \mathrm{~s}$.

REGRUTOVÁ, Lenka. Transformácia slovenskej ludovej rozprávky do prostredia akusticko-auditívnej komunikácie. [online]. [cit. 28. 3. 2020]. In Jazyk a reč, 2012, roč. 3, č. 9, s. 1 - 6. Dostupné na internete: http://www.ff.unipo.sk/jak/rus/9_2012/regrutova.pdf.

ROUBAL, Jan. Hledání souřadnic a kontextů divadla (Př́spěvky k současné německé divadelní teorii, 
k jejím otázkám, možným výzvám a inspiracím). Brno : Janáčkova akademie múzických umění, 2018. 201 s. ISBN 978-80-7460-134-7.

RUFFINI, Franco. Text a jeviště. In BARBA, Eugenio - SAVARESE, Nicola. Slovník divadelní antropologie. Praha : Institut umění, Divadelní ústav, Nakladatelství Lidové noviny, s. 238 242. ISBN 80-7106-369-X.

SŁAWIŃSKA, Irena. Odczytanie dramatu. In DEGLER, J. Problemy teorii dramatu i teatru. Wrocław : Wydawnictwo Uniwersytetu Wrocławskiego, 1988, s. 63 - 80. ISBN 83-229-0276-X.

SPYRKA, Lucyna. Koncepcja przekładu Lubomíra Feldka w kontekście słowackiej myśli przekładoznawczej. In Przekłady Literatur Słowiańskich, 2016, roč. 7, č. 1, s. 64 - 77. ISSN 1899-9417.

ŠPAŇÁR, Július - HRABOVSKÝ, Jozef. Latinsko-slovenský - slovensko-latinský slovník. Bratislava : Slovenské pedagogické nakladatel'stvo, 1987. $1224 \mathrm{~s}$.

TVRDÝ, Peter. Slovník slovensko-latinský. Ružomberok : „Lev“ a Kníhtlačiarsky a nakladatel'ský spolok účastinná spoločnost', 1923. $345 \mathrm{~s}$.

UBERSFELD, Anna. Czytanie teatru I. Warszawa : Wydawnictwo Naukowe PWN, 2007. 244 s. ISBN 978-83-01-13571-3.

VALENTOVÁ, Mária - REŽNÁ, Miroslava. Aspekty prekladového textu. Antológia prác o preklade. Nitra : Univerzita Konštantína Filozofa, 2011. 309 s. ISBN 978-80-558-0010-3.

WYSŁOUCH, Seweryna: Adaptacja filmowa - przekłademczy montażem? In Przestrzenie Teorii, 2014, roč. 23, č. 22, s. 223 - 227. ISSN 1644-6763.

ZÁHORÁK, Andrej. Uvažovanie o audiovizuálnom preklade v kontexte ruskej translatológie. In

ZIENKIEWICZ-FRANCZAK, Ewa. Przekład intersemiotyczny w edukacji polonistycznejs. [Dizertačná práca]. Poznań : Uniwersytet im. Adam Mickiewicz, 2018. 145 s. [online]. [cit. 22. 3. 2020]. Dostupné na internete: https://repozytorium.amu.edu.pl/handle/10593/22924.

ŽANTOVSKÁ, Irena. Divadlo jako komunikační médium. Praha : Nakladatelství Akademie múzických umění, 2012. 233 s. ISBN 978-80-7331-243-5.

ŽELONKA, Ján. Multimodálny prístup k programovým štruktúram slovenských televíznych vysielatelov: právne normy verzus prax. In PAULÍNYOVÁ, Lucia - JANECOVÁ, Emília. Audiovizuálny preklad 2. Za hranicami prekladu. Nitra : Univerzita Konštantína Filozofa, 2015, s. 11 - 34. ISBN 978-80-558-0923-6.

Dagmar Inštitorisová

Katedra masmediálnej komunikácie a reklamy

Filozofická fakulta UKF

Dražovská 4

94974 Nitra

e-mail: dinstitorisova@ukf.sk 